University of New Hampshire

University of New Hampshire Scholars' Repository

$9-2009$

\title{
Taking stock of arctic sea ice and climate
}

\author{
Mary-Louise Timmermans \\ Woods Hole Oceanographic Institution \\ Jennifer Francis \\ Rutgers University - New Brunswick/Piscataway \\ Audrey Proshutinsky \\ Woods Hole Oceanographic Institution \\ Lawrence C. Hamilton \\ University of New Hampshire, lawrence.hamilton@unh.edu
}

Follow this and additional works at: https://scholars.unh.edu/soc_facpub

Part of the Sociology Commons

\section{Recommended Citation}

Timmermans, M.-L., Francis, J., Proshutinsky, A., Hamilton, L. Taking stock of arctic sea ice and climate. (2009) Bulletin of the American Meteorological Society, 90 (9), pp. 1351-1353.

This Article is brought to you for free and open access by the Sociology at University of New Hampshire Scholars' Repository. It has been accepted for inclusion in Sociology Scholarship by an authorized administrator of University of New Hampshire Scholars' Repository. For more information, please contact Scholarly.Communication@unh.edu. 


\section{TAKING STOCK OF ARCTIC SEA ICE AND CLIMATE}

by Mary-Louise Timmermans, Jennifer Francis, Andrey Proshutinsky, and LaWrence Hamilton

$\mathrm{T}$ he Arctic is characterized by strong natural variability, intricate feedbacks, and a multiyear memory for ocean-ice-atmosphere processes. Recent and unprecedented change to the Arctic climate system, however, appears to have been forced by both anthropogenic change and natural variability, together with feedbacks among the sea ice, atmosphere, and ocean. This was the consensus of discussions and presentations during a symposium at the Woods Hole Oceanographic Institution in late 2008. Changes in the Arctic include increasing atmospheric and oceanic temperatures, ocean freshening, unusual atmospheric circulation patterns, and the decline of sea ice (e.g., Richter-Menge et al. 2008). The summers of 2007 and 2008 saw the most dramatic sea-ice losses yet, with the extent of summer sea ice dropping more than one-third below the average values. This article, in summarizing the discussion themes and general conclusions of scientists who participated in the symposium, highlights the immense complexity in the cause-and-effect relationships among the

Affiliations: Timmermans And Proshutinsky-Woods Hole Oceanographic Institution, Woods Hole, Massachusetts; FrancIs-Rutgers, the State University of New Jersey, New Brunswick, New Jersey; HaMILTON-University of New Hampshire, Durham, New Hampshire CORRESPONDING AUTHOR: M.-L. Timmermans, Woods Hole Oceanographic Institution, Woods Hole, MA 02543

E-mail: mtimmermans@whoi.edu

DOI: $10.1175 / 2009 B A M S 2882.1$

In final form 25 June 2009

(C)2009 American Meteorological Society

\section{SYMPOSIUM ON ARCTIC SEA ICE AND CLIMATE \\ WHAT: Fifteen scientists, representing a wide range of expertise on the Arctic environment, met to discuss the state of the Arctic system in the context of climate change. \\ WHEN: 5-7 November 2008 \\ WHerE: Woods Hole, Massachusetts}

Arctic atmosphere, sea ice, and ocean. The scientific presentations have been posted on the symposium's Web site (www.whoi.edu/sites/arctic2008).

\section{ATMOSPHERIC CIRCULATION PATTERNS.}

Arctic climate patterns of this decade are distinct from any time during the twentieth century (Overland et al. 2008). The period of 2000-07 was characterized by unusual meridional flow toward the North Pole (Overland and Wang 2005; Overland et al. 2008). These anomalous winds resulted in sea-ice loss via enhanced ice transport; analysis of sea-ice drift indicates that the prevailing summer circulation in recent years has resulted in a distinct positive trend in the export of sea ice from the Arctic, contributing up to $30 \%$ of the sea-ice retreat during the past several years (Kwok 2008; Ogi et al. 2008). It is telling that a similar meridional atmospheric pattern occurred in the late 1930s but did not result in the massive ice losses seen in recent years. It may be that increasing temperatures of the last several decades now impede recovery of an ice pack affected by anomalous winds, with ice retreat further enhancing warm autumn temperature anomalies (Overland et al. 2008; Francis et al. 2009). 
Another natural atmospheric climate pattern that impacts sea-ice extent is the Arctic Oscillation (AO); the 2007 and 2008 winter $\mathrm{AO}$ index was more positive than in previous years (a positive phase of the $\mathrm{AO}$ is typically associated with warmer temperatures and export of ice from the Arctic Ocean), although not as strongly positive as in the early 1990s when sea-ice loss was less. It remains to be seen whether a future return to a consistently strongly negative $\mathrm{AO}$ (typically associated with cooler temperatures and sequestered ice in the Arctic) would be sufficient to reverse the trend of the recent warming and ice decline. Although it would seem that increasing temperatures and iceocean feedbacks leave the Arctic climate more susceptible to natural atmospheric variability, it is unclear to what extent global climate change influences changes in the atmospheric circulation.

\section{A THINNER, MORE VULNERABLE SEA-ICE} COVER. The increased vulnerability of the Arctic system to anomalous atmospheric forcing can be argued from the perspective that recent ice loss is the result of a long-term preconditioning to thinner ice. Lindsay et al. (2009) use a coupled ice-ocean model to show that the record minimum summer sea-ice extents in 2007 and 2008 may be the result of a general thinning of sea ice in a warming climate over past decades. The mean ice thickness and compactness over the entire Arctic basin began to decline consistently beginning in the late 1980s (Lindsay and Zhang 2005; Rigor and Wallace 2004). Lindsay et al. (2009) demonstrate that the recent anomalous wind patterns that blew the ice from the Pacific to the Atlantic side of the Arctic basin, where a significant fraction was pushed out of the Arctic Ocean through Fram Strait, would have been less influential without prior thinning of the ice pack-a less compact ice pack is more susceptible to advection by the wind and currents.

While measurements of ice thickness have been elusive, thickness information has increased since 2003 through the use of satellites. Ice, Cloud, and Land Elevation Satellite (ICESat) laser altimeter elevation profiles provide estimates of sea-ice freeboard (the elevation of the ice and snow layer above the level of open water), from which thickness can be inferred after accounting for the hydrostatic load of the snow layer (Kwok and Cunningham 2008). Similarly, satellite radar altimetry data from the European Space Agency (ESA) European Remote Sensing Satellites ERS-1, ERS-2, and Envisat are also used to infer ice thickness (e.g., Laxon et al. 2003; Giles et al. 2008). The evolution of the multiyear ice thickness between 2002 and 2008 (before and after the September 2007 ice-extent minimum) reveals that the Arctic-wide average value was $0.26 \mathrm{~m}$ less during winter 2007/08 than the average winter ice thickness for the $5 \mathrm{yr}$ preceding (Giles et al. 2008). Giles et al. (2008) also show that the ice-extent minimum in fall 2007 was followed by reduced ice thicknesses the following winter, with the largest decrease of $0.49 \mathrm{~m}$ in the western Arctic. While thinning trends in permanent ice cover are emerging, continuous measurements of ice draft (i.e., the thickness of the part of the ice that sits below the water surface), using underwater sonar in the Beaufort Sea since 1990, indicate no trend in seasonal ice thickness (Melling et al. 2005). This result is consistent with longer-term measurements (since the 1930s) in the seasonal land-fast ice.

FEEDBACKS AND IMPACTS. Perovich et al.'s (2008) analysis of autonomous ice-mass balance buoy (IMB) thickness measurements showed that absorption of solar radiation in the Arctic Ocean surface layer in summer 2007 led to greatly enhanced melting of the bottom surface of multiyear ice in the Beaufort Sea. An increase in the area of open water that summer resulted in a large positive anomaly in solar heat input to the upper ocean, triggering a strong ice-albedo feedback whereby more open water resulted in the absorption of more solar heat, which in turn resulted in more melting and more open water. The excess warming of the upper ocean contributed to delayed freezing in fall 2007 (Comiso et al. 2008), in effect lengthening the melt season.

Observations of atmospheric conditions following summers with anomalous sea-ice conditions suggest that the loss of Arctic sea ice will affect the exchange of heat and moisture between the surface and atmosphere, leading to changes in the boundary layer, clouds, and weather patterns in the ensuing fall and winter (Francis et al. 2009). The substantial ice loss in summer 2007, for example, was followed by a substantial increase in cloud amount over the areas of newly exposed water during autumn (Levinson and Larimore 2008), likely due to increased evaporation. Warming of the lower troposphere and increased emission of infrared radiation toward the surface also retard the formation of sea ice. Such consequences demonstrate the difficulties inherent in ascertaining how the atmospheric circulation responds to Arctic, and global, climate change.

Corresponding changes in the seasonal timing of ice growth and retreat ultimately impact Arctic ecosystems and small Arctic communities. Annual primary productivity in the Arctic Ocean has been increasing over the last decade, in part because of a 
longer growth season that arises under greater open water extent (Arrigo et al. 2008). Further, some events in biology are prompted not by their immediate environment but rather by timing; hence, in a rapidly changing Arctic a disparity between biology and the physical environment can arise. Later-forming sea ice also leads to less protection from the waves of fall storms, affecting coastal communities such as Kivalina and Shishmaref. Around the Arctic, migration and other demographic indicators often respond quickly to external pressures and bear watching through the coming environmental changes (Hamilton and Mitiguy 2008).

CONCLUDING REMARKS. Although continued Arctic change is expected under present anthropogenic forcing, the rate and consequences of this change are less clear. It may be that feedback mechanisms, steady warming, and natural fluctuations will cause further dramatic reductions in summer ice, or the Arctic may remain in a new, stable state of reduced seasonal ice cover for many years. With emphasis on sustained Arctic observations, the coming decades will provide new insights into the complexities of the Arctic climate system and how changes will affect the biological and human communities within and beyond its boundaries.

\section{REFERENCES}

Arrigo, K. R., G. van Dijken, and S. Pabi, 2008: Impact of a shrinking Arctic ice cover on marine primary production. Geophys. Res. Lett., 35, L19603, doi:10.1029/2008GL035028.

Comiso, J. C., C. L. Parkinson, R. Gersten, and L. Stock, 2008: Accelerated decline in the Arctic sea ice cover. Geophys. Res. Lett., 35, L01703, doi:10.1029/2007GL031972.

Francis, J. A., W. Chan, D. Leathers, J. Miller, and D. Veron, 2009: Winter Northern Hemisphere weather patterns remember summer Arctic sea-ice extent. Geophys. Res. Lett., 36, L07503, doi:10.1029/2009GL037274.

Giles, K. A., S. W. Laxon, and A. L. Ridout, 2008: Circumpolar thinning of Arctic sea ice following the 2007 record ice extent minimum. Geophys. Res. Lett., 35, L22502, doi:10.1029/2008GL035710.

Hamilton, L. C., and A. Mitiguy, cited 2008: Population dynamics in Arctic Alaska: Graphical views of community change. [Available online at www. carseyinstitute.unh.edu/alaska-indicators.htm.]

Kwok, R., 2008: Summer sea ice motion from the 18-GHz channel of AMSR-E and the exchange of sea

\section{MEETING PARTICIPANTS}

$\begin{array}{lll}\text { C. Ashjian } & \text { S. Laxon } & \text { D. Perovich } \\ \text { J. Cassano } & \text { R. Lindsay } & \text { A. Proshutinsky } \\ \text { J. Francis } & \text { P. Matrai } & \text { V. Smolyanitsky } \\ \text { J.C. Gascard } & \text { H. Melling } & \text { M.-L. Timmermans } \\ \text { L. Hamilton } & \text { M. Miles } & \text { T. Weingartner } \\ \text { R. Kwok } & \text { J. Overland } & \end{array}$

ice between the Pacific and Atlantic sectors. Geophys. Res. Lett., 35, L03504, doi:10.1029/2007GL032692.

— , and G. F. Cunningham, 2008: ICESat over Arctic sea ice: Estimation of snow depth and ice thickness. J. Geophys. Res., 113, C08010, doi:10.1029/2008JC004753.

Laxon, S., N. Peacock, and D. Smith, 2003: High interannual variability of sea ice thickness in the Arctic region. Nature, 425, 947-950.

Levinson, D. H., and J. H. Lawrimore, 2008: State of the climate in 2007. Bull. Amer. Meteor. Soc., 89, S1-S179.

Lindsay, R. W., and J. Zhang, 2005: The thinning of arctic sea ice, 1988-2003: Have we passed a tipping point? J. Climate, 18, 4879-4894.

— - _ A. Schweiger, M. Steele, and H. Stern, 2009: Arctic sea ice retreat in 2007 follows thinning trend. J. Climate, 22, 165-176.

Melling, H., D. A. Riedel, and Z. Gedalof, 2005: Trends in the draft and extent of seasonal pack ice, Canadian Beaufort Sea. Geophys. Res. Lett., 32, L24501, doi:10.1029/2005GL024483.

Ogi, M., I. G. Rigor, M. G. McPhee, and J. M. Wallace, 2008: Summer retreat of Arctic sea ice: Role of summer winds. Geophys. Res. Lett., 35, L24701, doi:10.1029/2008GL035672.

Overland, J. E., and M. Wang, 2005: The Arctic climate paradox: The recent decrease of the Arctic Oscillation. Geophys. Res. Lett., 32, L06701, doi:10.1029/2004GL021752.

—_ _ _ and S. Salo, 2008: The recent Arctic warm period. Tellus, 60A, 589-597.

Perovich, D. K., J. A. Richter-Menge, K. F. Jones, and B. Light, 2008: Sunlight, water, and ice: Extreme Arctic sea ice melt during the summer of 2007. Geophys. Res. Lett., 35, L11501, doi:10.1029/2008GL034007.

Richter-Menge, J., and Coauthors, cited 2008: Arctic Report Card 2008. [Available online at www.arctic. noaa.gov/reportcard.]

Rigor, I. G. and J. M. Wallace, 2004: Variations in the age of Arctic sea-ice and summer sea-ice extent. Geophys. Res. Lett., 31, L09401, doi:10.1029/2004GL019492. 


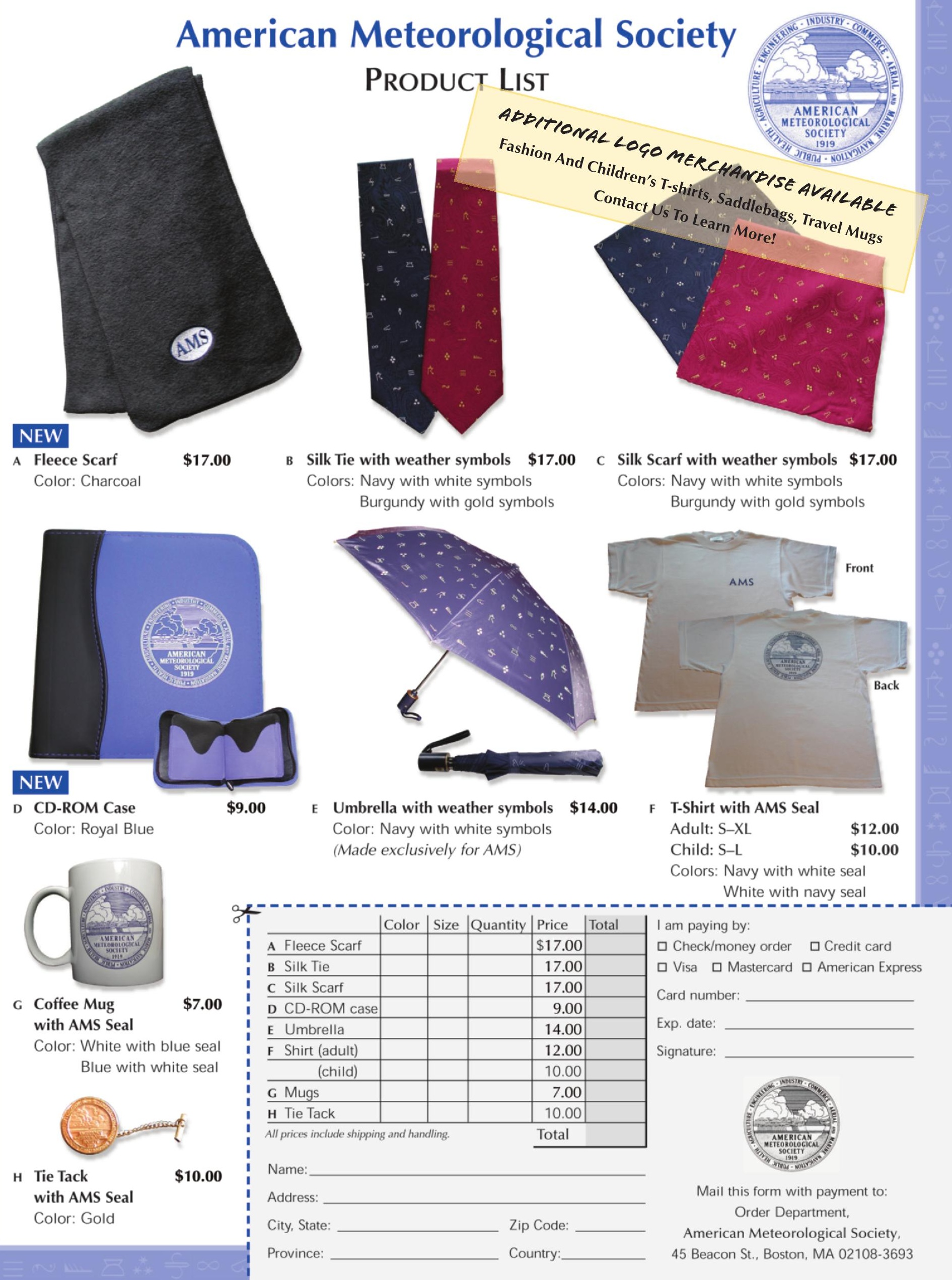

